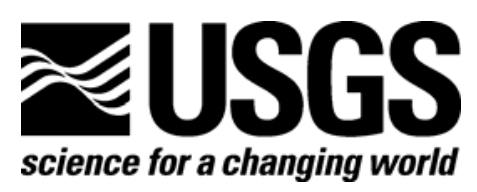

\title{
USGS Analysis of the Australian UNCLOS Submission
}

By Deborah R. Hutchinson and Robert W. Rowland

Open-File Report 2006-1073

U.S. Department of the Interior

U.S. Geological Survey 


\title{
U.S. Department of the Interior \\ Gale A. Norton, Secretary
}

\section{U.S. Geological Survey \\ P. Patrick Leahy, Acting Director}

\author{
U.S. Geological Survey, Reston, Virginia
}

For Additional Information:

See the United Nations web page on the United Nations Convention on the Law of the Sea at http://www.un.org/Depts/los/index.htm, and the Executive Summary of the Australian UNCLOS submission at http://www.un.org/Depts/los/clcs_new?submission_files/submission_aus.htm.

\author{
Contact \\ Deborah R. Hutchinson \\ U.S. Geological Survey \\ 384 Woods Hole Road \\ Woods Hole, MA, 02543 \\ dhutchinson@usgs.gov \\ 508-457-2263 \\ Robert W. Rowland \\ U.S. Geological Survey, Retired \\ 55825 River Shore Lane \\ Elkhart, IN 46516 \\ rrowland1@attglobal.net
}

For product and ordering information:

World Wide Web: http://www.usgs.gov/pubprod

Telephone: 1-888-ASK-USGS

For more information on the USGS-the Federal source for science about the Earth, its natural and living resources, natural hazards, and the environment:

World Wide Web: http://www.usgs.gov

Telephone: 1-888-ASK-USGS

\section{Suggested citation}

Hutchinson, D.R., and Rowland, R.W., 2006, USGS Analysis of the Australian UNCLOS Submission: U.S.

Geological Survey Open-File Report 2006-1073, 19 p., http://pubs.usgs.gov/of/2006/1073.

Any use of trade, product, or firm names is for descriptive purposes only and does not imply endorsement by the U.S. Government, nor does the interpretation presented here reflect official U.S. Government policy.

Although this report is in the public domain, permission must be secured from the individual copyright owners to reproduce any copyrighted material contained within this report. 


\section{Contents}

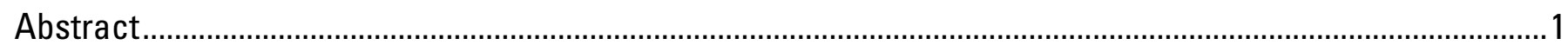

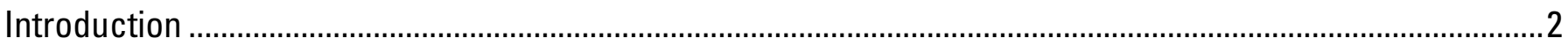

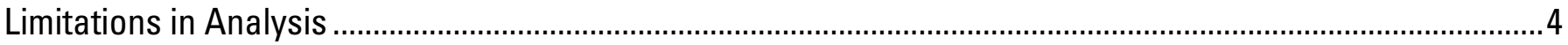

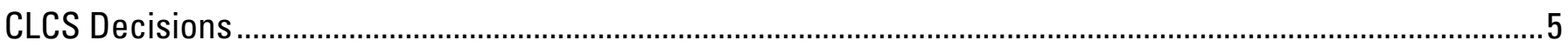

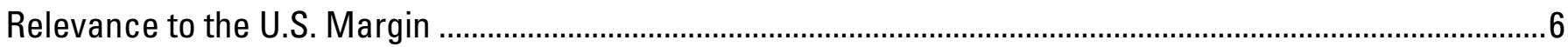

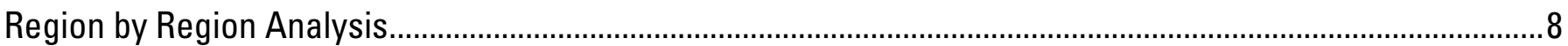

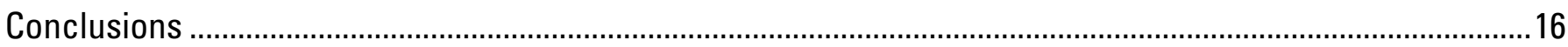

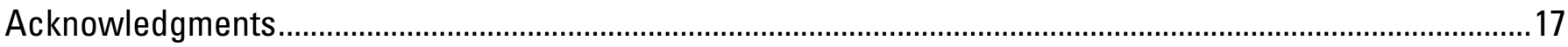

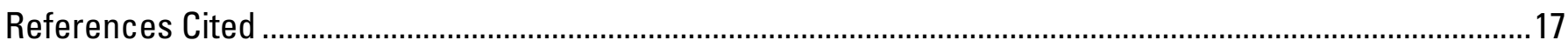

\section{Figures}

1. Map showing the 200-nm Exclusive Economic Zone (EEZ) of Australia excluding the Australian/Antarctic Territory. Names for the 10 areas with extended continental shelf regions correspond to names used in Table 1. For actual ECS regions, see http://www.un.org/Depts/los/clcs_new/submissions_files/aus04/Maps/aus_map_es_1.pdf.

Bathymetry from ETOP02; Australian maritime boundaries from (AMBIS, 2001) ...........................

2. Relative ECS land area of regions 1-10 of the Australian submission using areas from Table 1. Colors proceed in a clockwise direction from the 12 o'clock position around the diagram (note that Argo is barely discernible)

3. Comparison of the color gradations used to depict bathymetry in the 10 ECS regions of the Australian submission. Numbers are the same as the regions described in the Australian Executive Summary and used in this report. The bars are aligned on the $0-\mathrm{m}$ and 2,500-m depths

4. Kerguelen EEZ (white) and approximate extended continental shelf boundary (pink). Points shown are $\mathrm{S} 1$ (at the intersection of the westernmost point of the France-Australia bilateral boundary and the Australian EEZ) and point 2 (the first ECS point). Dashed line shows an alternative method of linking the ECS to the EEZ. McDonald Island is a small volcanic rock feature near Heard Island and is not visible at the scale of this map

5. Bathymetric map of the Kerguelen Plateau region using a different color scheme than that of the Australian submission. NKP - Northern Kerguelen Plateau; CKP - Central Kerguelen Plateau; SKP Southern Kerguelen Plateau. Land areas are shown as gray: Heard and McDonald Islands are immediately beneath and to the left of CKP; the Îles Kerguelen (Îles de Désolation) archipelago is just below the "P" in NKP. This color scheme emphasizes water depths less than 2,500 $\mathrm{m}$ (in greens) and greater than 2,500 $\mathrm{m}$ (in blues). The $2500-\mathrm{m}$ isobath is shown as a dotted contour. In this image, the color scaling minimizes the appearance of connectivity from the CKP to either Elan Bank or SKP This map was created in a Geographic Information System using ETOPO2 bathymetry ......................10

6. Map showing the location of Elizabeth and Middleton Reefs relative to Lord Howe Island. Contour Interval is $1,000 \mathrm{~m}$ 
7. Bathymetry around the Wallaby and Exmouth Plateaus showing the extension of Joey Rise north of the Exmouth Plateau. The linear morphologic boundary formed by Wombat Plateau and Platypus Spur is created by a fault separating oceanic crust to the north from continental transitional crust of the Exmouth Plateau. Contour Interval 1,000 m

\section{Tables}

1. Statistics for the Australian UNCLOS Submission

2. Relative Land Areas of the Australian UNCLOS Article 76 Submission

\section{Conversion Factors}

\section{Inch/Pound to SI}

\begin{tabular}{lll}
\hline \multicolumn{1}{c}{ Multiply } & \multicolumn{1}{c}{ By } & \multicolumn{1}{c}{ To obtain } \\
\hline foot $(\mathrm{ft})$ & Length & \\
mile $(\mathrm{mi})$ & 0.3048 & meter $(\mathrm{m})$ \\
mile, nautical $(\mathrm{nmi})$ & 1.609 & kilometer $(\mathrm{km})$ \\
\hline Area & 1.852 & kilometer $(\mathrm{km})$ \\
\hline square mile $\left(\mathrm{mi}^{2}\right)$ & & \\
\hline
\end{tabular}

\section{SI to Inch/Pound}

\begin{tabular}{lcl}
\hline \multicolumn{1}{c}{ Multiply } & By & \multicolumn{1}{c}{ To obtain } \\
\hline meter $(\mathrm{m})$ & Length & \\
kilometer $(\mathrm{km})$ & 3.281 & foot (ft) \\
kilometer $(\mathrm{km})$ & 0.6214 & mile (mi) \\
meter $(\mathrm{m})$ & 0.5400 & mile, nautical (nmi) \\
\hline Area & 1.094 & yard (yd) \\
\hline square kilometer $\left(\mathrm{km}^{2}\right)$ & & \\
square kilometer $\left(\mathrm{km}^{2}\right)$ & 247.1 & acre \\
\hline
\end{tabular}




\title{
USGS Analysis of the Australian UNCLOS Submission
}

\author{
By Deborah R. Hutchinson and Robert W. Rowland
}

\begin{abstract}
In November 2004, the Government of Australia made a submission to the Commission on the Limits of the Continental Shelf (CLCS) for 10 extended continental shelf (ECS) regions, utilizing Article-76 of the United Nations Convention on the Law of the Sea (UNCLOS). With information provided in the Australian Executive Summary, the USGS examined the 10 regions of the submission from geological, morphological, and resource perspectives. By their own request, the Australians asked that CLCS take no action on the Australian-Antarctic Territory. The major limitation in this analysis is that no bathymetric soundings or detailed hydrographic profiles were provided in the Australian Executive Summary that might show why the Foot of the Slope (FOS) was chosen or where the 2,500-m contour is located. This represents a major limitation because more than half of the 4,205 boundary points utilize the bathymetric formula line and more than one-third of them utilize the bathymetric constraint line.
\end{abstract}

CLCS decisions on the components of this submission may set a precedent for how ECSs are treated in future submissions. Some of the key decisions will cover (a) how a "natural prolongation" of a continental margin is determined, particularly if a bathymetric saddle that appears to determine the prolongation is in deep water and is well outside of the 200-nm limit (Exmouth Plateau), (b) defining to what extent that plateaus, rises, caps, banks and spurs that are formed of oceanic crust and from oceanic processes can be considered to be "natural prolongations" (Kerguelen Plateau), (c) to what degree UNCLOS recognizes reefs and uninhabited micro-islands (specifically, rocks and/or sand shoals) as islands that can have an EEZ (Middleton and Elizabeth Reefs north of Lord Howe Island), and (d) how the Foot of the Slope (FOS) is chosen (Great Australian Bight).

The submission contains situations that are relevant to potential future U.S. submissions and are potentially analogous to certain features of the US margins. The Australian margin has significant geological and morphological variety, similar to the US margin and gives a good idea of the complexity of issues related to the U.S. margin. Decisions about basins and ridges in the Lord Howe Rise and Three Kings Ridge regions will likely bear on the status of ridges in the Arctic, such as Lomonosov Ridge. The Naturaliste Plateau and the South Tasman Rise appear to have parallels with the Chukchi Plateau in the Arctic and the Blake Plateau off the southeastern U.S. The ECS on Macquarie Island/Ridge may determine how boundaries along ridges such as the Mariannas are treated. 


\section{Introduction}

On 15 November 2004, the Government of Australia made a submission to the Commission on the Limits of the Continental Shelf (CLCS) for 10 extended continental shelf (ECS) regions. This submission utilized the United Nations Convention on the Law of the Sea (UNCLOS) and specifically relied on Article 76 "The Definition of a Continental Shelf." The total area of the Australian submission seaward of the $200-\mathrm{nm}$ limit as measured from the territorial sea baseline is large: 3,371,990 $\mathrm{km}^{2}$ as summarized in Table 1 and Fig. 2. Excluding the Australian/Antarctica Territory, these regions add a (submerged) land area to Australian jurisdiction that is nearly $30 \%$ of the 200-nautical mile (nm) Exclusive Economic Zone (EEZ) or $45 \%$ of the total area of terrestrial Australia and its islands (Table 2). The ECS Australian Antarctic Territory (region 2) is the second largest land area of the submission, but Australia requested that the CLCS take no action for the time being. This report is primarily an examination of the 10 ECS regions of the Australian UNCLOS submission.

Prefacing this analysis are three over-riding issues that are considered in greater detail:

(a) Limitations in Analysis: No bathymetric soundings or detailed hydrographic profiles were provided in the Executive Summary. Notwithstanding this limitation, we have strived to evaluate each region, with respect to the text of Article 76.

(b) CLCS Decisions: CLCS decisions on the components of this submission may set a precedent for future ECS submissions by other nations, potentially including the U.S.

(c) Relevance to the U.S. margin: The submission contains features that are potentially analogous to submarine geological and morphological features on the U.S. margin and to island commonwealths and territories of the U.S.

Table 1: Statistics for the Australian UNCLOS Submission

\begin{tabular}{|c|c|c|c|c|c|c|c|c|}
\hline \multirow[b]{2}{*}{ Area } & \multicolumn{2}{|c|}{ Statistics } & \multicolumn{2}{|c|}{ Formula Lines } & \multicolumn{2}{|c|}{ Constraint Lines } & \multicolumn{2}{|c|}{ Other Points } \\
\hline & $\begin{array}{c}\text { Area } \\
\text { Expanded km² }\end{array}$ & $\begin{array}{c}\text { Total } \\
\text { No. Pts }\end{array}$ & $\begin{array}{c}\text { Sediment } \\
\text { Thick }\end{array}$ & Bathy & $350 \mathrm{~nm}$ & $2500+$ & $\begin{array}{l}\text { EEZ } \\
\text { Pts }\end{array}$ & $\begin{array}{c}\text { Intl } \\
\text { Bound. }\end{array}$ \\
\hline Argo & 4,736 & 3 & & 1 & & & 1 & 1 \\
\hline Australia-Antarctica & 686,821 & 157 & 60 & 69 & 19 & & 9 & \\
\hline Great Australian Bight & 68,837 & 89 & 1 & 86 & & & 2 & \\
\hline Kerguelen Plateau & $1,185,038$ & 1,396 & & 555 & & 837 & 2 & 1 \\
\hline Lord Howe Rise & 265,717 & 118 & 1 & 113 & 1 & & 2 & 1 \\
\hline Macquarie Ridge & 81,719 & 402 & & 400 & & & 1 & 1 \\
\hline Naturaliste Plateau & 154,331 & 424 & & 322 & 10 & 90 & 2 & \\
\hline South Tasman Rise & 311,640 & 647 & 4 & 641 & & & 2 & \\
\hline Three Kings Ridge & 48,420 & 3 & & 2 & & & & 1 \\
\hline Wallaby/Exmouth Pl. & 564,731 & 966 & & 190 & 231 & 543 & 2 & \\
\hline Total & $3,371,990$ & 4,205 & 66 & 2,379 & 261 & 1,470 & 23 & 5 \\
\hline
\end{tabular}




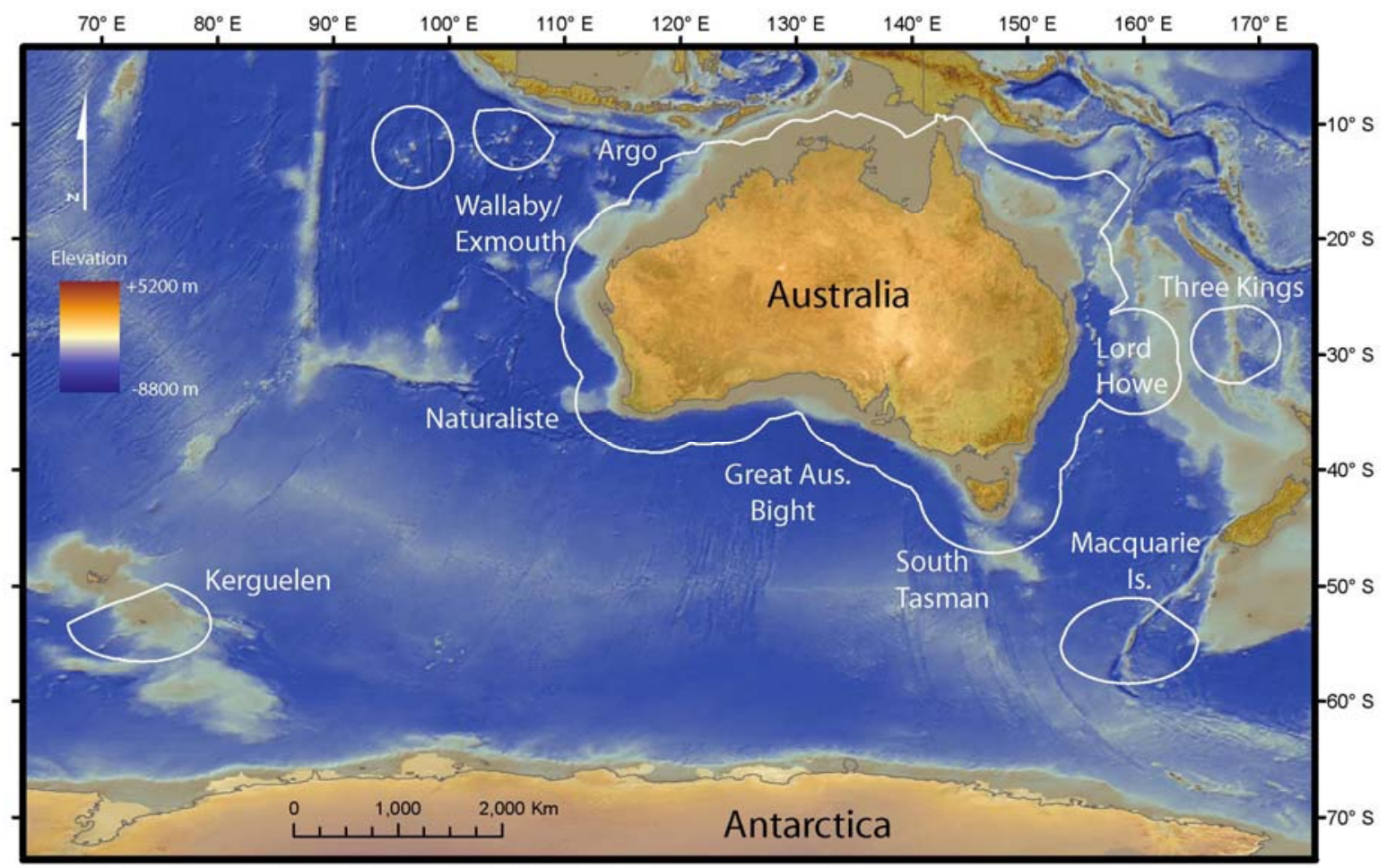

Figure 1. Map showing the 200-nm Exclusive Economic Zone (EEZ) of Australia excluding Antarctica. Names for the 10 areas with extended continental shelf regions correspond to names used in Table 1. For actual ECS regions, see

http://www.un.org/Depts/los/clcs_new/submissions_files/aus04/Maps/aus_map_es_1.pdf. Bathymetry from ETOP02; Australian maritime boundaries from (AMBIS, 2001).

Table 2: Relative Land Areas of the Australian UNCLOS Article 76 Submission*

\begin{tabular}{|l||l|l|l|}
\hline \multicolumn{1}{|c|}{ Location } & \multicolumn{1}{c|}{ Land Area $\left.\mathbf{( k m}^{\mathbf{2}}\right)$} & \multicolumn{1}{c|}{ EEZ Area $\left.\mathbf{( k m}^{\mathbf{2}}\right)$} & \multicolumn{1}{c|}{ ECS Area $\left(\mathbf{k m}^{2}\right)$} \\
\hline \hline Heard and McDonald Is. & 370 & 410,722 & $1,185,038$ \\
\hline Christmas Island & 1 & 325,021 & 0 \\
\hline Cocos Islands & 14 & 463,371 & 0 \\
\hline Norfolk Island & 35 & 428,618 & 48,420 \\
\hline Macquarie Island & 128 & 471,837 & 81,719 \\
\hline Australia & $7,659,861$ & $6,048,681$ & $1,369,992$ \\
\hline Subtotal & $7,692,024$ & $8,148,250$ & $2,685,169$ \\
\hline Antarctica & $5,896,500$ & $6,100,000$ & 686,821 \\
\hline Total & 13,588524 & $14,248,250$ & $3,371,990$ \\
\hline
\end{tabular}

*Sources:

Land Area: http://www.ga.gov.au/education/facts/dimensions/externalterr/index.htm EEZ Area: http://www.ga.gov.au/education/facts/dimensions/oceans.jsp

Macquarie Island area: http://www.ga.gov.au/education/facts/landforms/largisle.htm

Note: Total land area includes islands that do not have separate EEZ boundaries. "Australia" EEZ area includes the EEZ around Lord Howe Island, which is continuous with the EEZ of the mainland. 


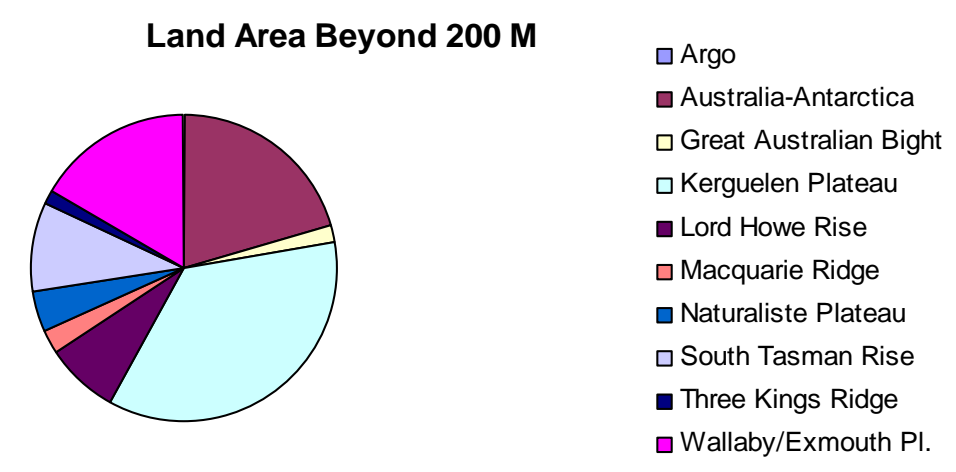

Figure 2. Relative ECS land area of regions 1-10 of the Australian submission using areas from Table 1. Colors proceed in a clockwise direction from the 12 o'clock position around the diagram (note that Argo is barely discernible).

\section{Limitations in Analysis}

No bathymetric measurements or hydrographic profiles are provided in the Executive Summary. Determination of the base of the continental slope and the location of the 2,500 meter isobath are required to utilize Article 76, paragraph 4 (a) (ii) (hereafter referred to as bathymetry line). More than half, or 2,379 of the 4,205 boundary points utilized by the Australians in defining the outer limits of their submission used this paragraph. There are not adequate data to fully evaluate the foot-of-the-slope (FOS) picks. Article 76, paragraph 4, (a) (i) (hereafter referred to as the sediment thickness line), relies on sediment thickness calculations. Only 66 of the ECS points use this criterion, and 60 of those are in the Australian/Antarctic region which is "not presently under consideration".

Because no FOS information is provided in the tables or Executive Summary we were not able to conduct a detailed analysis of the reasoning behind these points. This means we cannot determine whether the FOS is chosen consistently, whether it is based on "evidence to the contrary," and where it might be ambiguous and therefore subject to alternative interpretation. Part of the problem in evaluating the FOS criterion is also that the Lambert Conic Conformal Projection used in the regional maps will have small distortion in the scale bar related to distance from the two standard parallels where scale is true. This contributes to overall uncertainty in trying to "back out" either the FOS or 2,500-m location by measuring landward from the relevant outer limit points.

The 2,500-meter isobath is also used as part of the constraint limit. However, neither this isobath nor any other bathymetric contours are presented. Bathymetry is shown in color gradations, and the colors are not displayed consistently. Without the ability to redisplay the depth data more precisely, we are limited by color palettes that the Australians use in their maps. The 2,500-m contour, as summarized in Fig. 3, is variously shown as green (Great Australian Bight), yellow green (Argo, South Tasman Rise), yellow (Antarctica, Kerguelen, Lord Howe Rise), and yelloworange (Macquarie, Naturaliste, Wallaby). By stretching or shrinking the colors in the bar, slopes can look steeper or more gradual, and therefore create misimpressions about continuity and boundaries. 


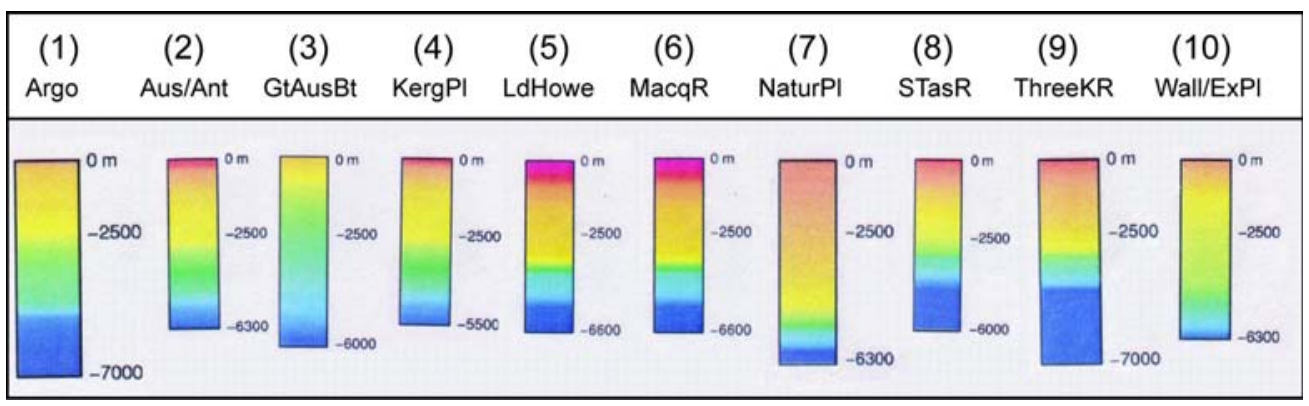

Figure 3. Comparison of the color gradations used to depict bathymetry in the 10 ECS regions of the Australian submission. Numbers are the same as the regions described in the Australian Executive Summary and used in this report. The bars are aligned on the 0 -m and 2,500-m depths.

\section{CLCS Decisions}

The Australian Submission raises major issues concerning the implementation of Article 76. In its evaluation and recommendation, the CLCS may set a precedent for how future submissions from other coastal States will be handled. The salient points are:

(1) How a "natural prolongation" of a continental margin is determined, particularly if a bathymetric saddle that appears to determine the prolongation is in deep water and is well outside of the 200-nm limit (see discussion on "Region 10: Wallaby and Exmouth Plateaus"). The continental margin around the Australian continent contains numerous examples of bathymetric saddles that connect features used to extend the continental-shelf boundary. One extreme example is Joey Rise at the north end of the Exmouth Plateau, a feature of unknown origin on oceanic crust. The Joey Rise has been used to extend the base of the continental slope (and therefore the continental-shelf boundary) north onto the Argo Abyssal Plain. The bathymetric saddle connecting Joey Rise to the Exmouth Plateau is in greater than 4,000-m water depth and lies more than $250 \mathrm{~km}$ outside the EEZ boundary.

(2) Defining to what extent that plateaus, rises, caps, banks and spurs that are formed of oceanic crust and from oceanic processes can be considered to be "natural prolongations" of continental margins (see discussion on "Region 4: Kerguelen Plateau"). The ECS for the Kerguelen Plateau originates with two exposed islands, Heard and McDonald Islands, which sit on a fossil oceanic spreading ridge now called the Central Kerguelen Plateau. The ECS includes two features that are geologically and morphologically distinct: Elan Bank and the Southern Kerguelen Plateau. Elan Bank is a micro-continental fragment of India that abuts the Central Kerguelen Plateau on its west in water depths of 2,500-3,000 m. Southern Kerguelen Plateau is an older plume-related, subsided volcanic edifice adjacent to the Central Kerguelen Plateau on its south, also in water depths of 2,500 - 3,000 $\mathrm{m}$. The extent to which these features can be considered natural prolongations of the geologically, morphologically, and perhaps bathymetrically distinct Central Kerguelen Plateau, may set a precedent for how oceanic features are determined to be part of a 
continental margin. How the base of the continental slope is chosen and what is considered "deep ocean floor" are also key considerations in this decision.

(3) To what degree UNCLOS recognizes reefs and uninhabited micro-islands" (specifically, rocks and/or sand shoals) as islands that can have an EEZ (see discussion on "Region 5: Lord Howe Rise"). North of Lord Howe Island, it appears that the two reefs, Middleton Reef and Elizabeth Reef, were used as baselines to define the 200-nm EEZ boundary. It is not addressed in the Executive Summary whether these reefs sustain "human habitation or economic life" and therefore qualify to be islands under UNCLOS. By admission of an Australian Government web site: "At high tide, when the Elizabeth and Middleton Reefs are almost totally submerged, they appear as only rings of white breakers, except for a small sand cay at Elizabeth Reef."

(4) How the Foot of the Slope (FOS) is chosen (see especially discussion on "Region 3: Great Australian Bight"). The bathymetric scales on the maps of each region utilize different colors that are stretched different amounts and therefore can be misleading about sea-floor slope, continuity, and depth. Removing these effects is absolutely essential to permit understanding how robust and consistent FOS estimates are. The Great Australian Bight represents a case where the FOS appears to be in water depths in excess of 4,000-5,000 m, depths more typical of continental rises.

\section{Relevance to the U.S. Margin}

A few general points can be made both about the Australian submission and its potential analogy to certain features of the U.S. margins.

(1) The Australian margin has great geological and morphological variety, similar to the U.S. margin: parts are passive margins; the north is under compression; some areas were formed by shear; extensive continental fragmentation has occurred in other areas; parts have undergone extensive volcanism; a few regions are non-volcanic; sediment thicknesses can be very large, or very small; buried plateaus lie adjacent to the margin. All of these situations also occur around the U.S., although the details and scales of features vary. Hence, this submission gives a good idea of the complexity of issues related to the U.S. continental margin.

(2) The Lord Howe Rise and Three Kings Ridge regions contain mixtures of continental crust, stretched continental crust, and mixed continental/oceanic crust. If CLCS makes any decisions regarding the basins and ridges in this region, those decisions may, in turn, bear on future submissions relating to the ridges and basins that underlie the Arctic Ocean (such as the Lomonosov Ridge).

(3) The Naturaliste Plateau and the South Tasman Rise appear to have parallels with the Chukchi Plateau in the Arctic and the Blake Plateau off the southeastern U.S.. These regions all share characteristics of complex tectonic histories, extended continental crust,

\footnotetext{
${ }^{1}$ Source: (http://www.deh.gov.au/coasts/mpa/elizabeth/features.html)
} 
displaced fragments, and juxtaposition with the continental margin. In as much as these Australian regions appear justified in having an ECS around them, the Chukchi Plateau (Borderland) may also be so justified.

(4) The ECS on Macquarie Island/Macquarie Ridge out to near or beyond $350 \mathrm{~nm}^{2}$ indicates that similar boundaries can be drawn on oceanic ridges that intersect the U.S. continental margin. The analog on the U.S. margin is the Gorda Ridge, although this ridge appears to lie totally within the U.S. EEZ. The Marianas Islands also lie on an oceanic ridge feature that deserves additional scrutiny.

(5) The large numbers of points defining the outer limit of the Australian ECS (4,205) are used to define arcs, rather than straight lines. This strategy maximizes the area considered part of the shelf and is worth noting.

(6) The 60-nm "line-segment" length from Article 76, paragraph 7 can be used to expand potential ECS. The best example from the Australian submission joins points S1 (FranceAustralia boundary) to point 2 (Figure 4). Otherwise, the boundary would wrap around to intersect the 200-nm limit. The area gained is small, but serves to maximize the ECS.

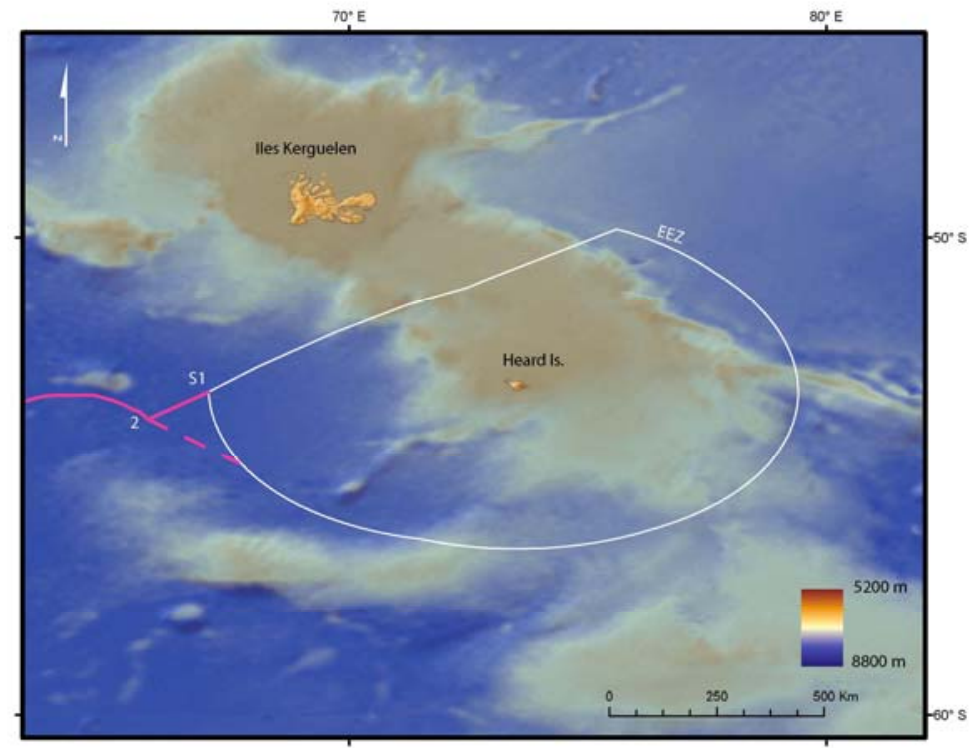

Figure 4. Kerguelen EEZ (white) and approximate extended continental shelf boundary (pink). Points shown are $\mathrm{S} 1$ (at the intersection of the westernmost point of the France-Australia bilateral boundary and the Australian EEZ) and point 2 (the first ECS point). Dashed line shows an alternative method of linking the ECS to the EEZ. McDonald Island is a small volcanic rock feature near Heard Island and is not visible at the scale of this map.

\footnotetext{
${ }^{2}$ It is not clear in the Executive Summary what the exact distance is, only that it is very close to $350 \mathrm{~nm}$.
} 


\section{Region by Region Analysis}

Region 1: ARGO (For ECS locations, see:

http://www.un.org/Depts/los/clcs_new/submissions_files/aus04/Maps/arg_map_es2.pdf )

Only three points in the Argo area are not based on international maritime boundaries with Indonesia: points 1 and 3 are on the 200-nm limit from Australia's territorial sea baseline. Point 2 looks reasonable as $60 \mathrm{~nm}$ from the base of the slope.

The Democratic Republic of Timor-Leste (East Timor) submitted strong objections to the Australian submission based on the lack of agreement on a mutual maritime boundary. TimorLeste is just east of the edge of the Australian map of the Argo region. Australia signed several maritime boundary agreements with Indonesia. When Timor-Leste achieved independence in 2002, some of these agreements upon which these boundaries were defined were nullified, bringing into question how revenues from shared energy and mineral resources, such as the Greater Sunrise petroleum field, will be divided. In mid-2005, the Timor and Australian governments were close to negotiating a revenue sharing plan, and were possibly deferring establishing a maritime boundary between the two nations in favor of an agreement on sharing revenues from petroleum and other seabed resources.

Region 2: AUSTRALIAN ANTARCTIC TERRITORY (For ECS location, see http://www.un.org/Depts/los/clcs_new/submissions_files/aus04/Maps/ant_map_es2.pdf )

The most significant portion of the Australian submission on Antarctica is its attached diplomatic note 89/2004, which requests the CLCS "not to take any action" regarding the Antarctic extended continental shelf. The United States, as well as other countries, also submitted a note acknowledging with appreciation Australia's request that the CLCS not take action on the Antarctic aspects of the submission, in light of Article IV of the Antarctic Treaty and the fact that the U.S. does not recognize any country's claim to territory in Antarctica.

None of the Antarctic boundary points lie beyond the $350 \mathrm{~nm}$ limit and the locations of most are based on the sediment thickness formula. There are very few public domain data for independently verifying sediment thicknesses or resources in these remote regions. Identification of the Antarctic extended continental shelf will be relevant to the Kerguelen Plateau because the boundary utilized for the south end of the Kerguelen Plateau is the $200 \mathrm{~nm}$ boundary for the Antarctic continental margin.

Region 3: GREAT AUSTRALIAN BIGHT (For ECS location, see http://www.un.org/Depts/los/clcs_new/submissions_files/aus04/Maps/gab_map_es2.pdf )

The extended continental shelf boundary essentially forms the base of a triangle that is formed by the northward sweep of the 200-nm limit to an apex in the Great Australian Bight. The ECS is defined by 89 points, points 1 and 89 being on the $200-\mathrm{nm}$ boundary. The rest of the points, excepting point 87 , are based on the bathymetric formula of $60-\mathrm{nm}$ from the FOS. Point 87 uses the sediment thickness criterion. Color designations on the figures in the Executive Summary are insufficient to determine where the foot of the slope lies, only that it must be well seaward of the $200-\mathrm{nm}$ boundary in water depths of about 4,000 -5,000 $\mathrm{m}$. These depths are more typical of the continental rise than the continental slope. 
The Great Australian Bight region is the trailing margin formed when the continents of Antarctica and Australia separated. A large sedimentary basin, the Bight Basin, underlies the margin and contains up to $15 \mathrm{~km}$ of sediments. Four sub-basins make up this part of the margin, of which the Ceduna contains the greatest sediment thicknesses (Hill and others, 2001). The geological, inner continental shelf is cut by numerous submarine canyons, and the extended continental shelf is underlain by often-faulted Cretaceous and Tertiary sediments (Krassay and Totterdell, 2003). The seabed added to the continental shelf contains the seaward extension of the Recherche and Ceduna Subbasins. Petroleum potential for the Ceduna Subbasin is considered promising (Krassay and Totterdell, 2003; Longley and others, 1999).

Region 4: KERGUELEN PLATEAU (For ECS location, see http://www.un.org/Depts/los/clcs_new/submissions_files/aus04/Maps/ker_map_es2.pdf )

The extended-continental-shelf boundary of the Kerguelen Plateau consists of 1,622 points that define the largest single region of the Australian submission that is beyond $200 \mathrm{~nm}: 1,185,038$ $\mathrm{km}^{2}$. The points are roughly split between the bathymetric formula and the bathymetric constraint line, i.e., morphology rather than geology appears to control the boundary. At its greatest extent, reaching to the 200-nm boundary of Antarctica, the boundary is more than $400 \mathrm{~nm}$ south of the Heard/McDonald Islands 200-nm boundary, indicating the Australians have interpreted the plateau as a submarine elevation with a natural prolongation that is not limited by either of the constraint lines. This region will test interpretations of ridges, submarine elevations, and natural prolongations. Decisions by CLCS may set a precedent for how Article 76 is applied to these large, mostly submerged features in other geographic locations.

Even though the Kerguelen boundary is defined exclusively by bathymetric factors, geology plays a role in understanding possible "evidence to the contrary" and whether the submerged portions of the plateau are natural prolongations of the Heard/McDonald Islands. As long ago as 1982, the Kerguelen Plateau was classified as an oceanic plateau (Nur and others, 1982). The Kerguelen Plateau and similar features are now classified as Large Igneous Provinces or LIP (Coffin and Eldholm, 1994). Both classifications acknowledge that oceanic plateaus and large igneous provinces are essentially oceanic, but may contain some continental crust. Three Ocean Drilling Program (ODP) legs have been devoted to understanding the Kerguelen Plateau: ODP Legs 119 and 120 in1987-1988 and Leg 183 in 1998-1999 (Coffin and others, 2000). This scientific drilling added significantly to our understanding of the rocks and the geologic processes which form the Kerguelen Plateau. For the purposes of this report we recognize the North Kerguelen Plateau, the Central Kerguelen Plateau, the South Kerguelen Plateau and Elan Bank (Coffin and others, 2000; Frey and others, 2000), as illustrated in Fig. 5. This division reflects the bathymetry and underlying geology. Each segment is examined in terms of its relationship with adjacent pieces and the applicability of UNCLOS Article 76, "the Continental Shelf".

The North Kerguelen Plateau (NKP) underlies the French-owned Îles Kerguelen (Îles de Désolation) archipelago. Most of this area is encompassed by the $200 \mathrm{~nm}$ radius of the Exclusive Economic Zone (EEZ) extending out from these islands. As the youngest of the Kerguelen Plateau segments, the NKP consists of oceanic volcanic rocks that erupted approximately 45-35 million years ago (Coffin and others, 2002). The Îles Kerguelen (Îles de Désolation) and the Australianowned Heard and MacDonald Islands to the south are separated by about $120 \mathrm{~nm}$ of open sea. As a result of overlapping EEZs, in 1982 France and Australia signed a Maritime Delimitation Treaty. 


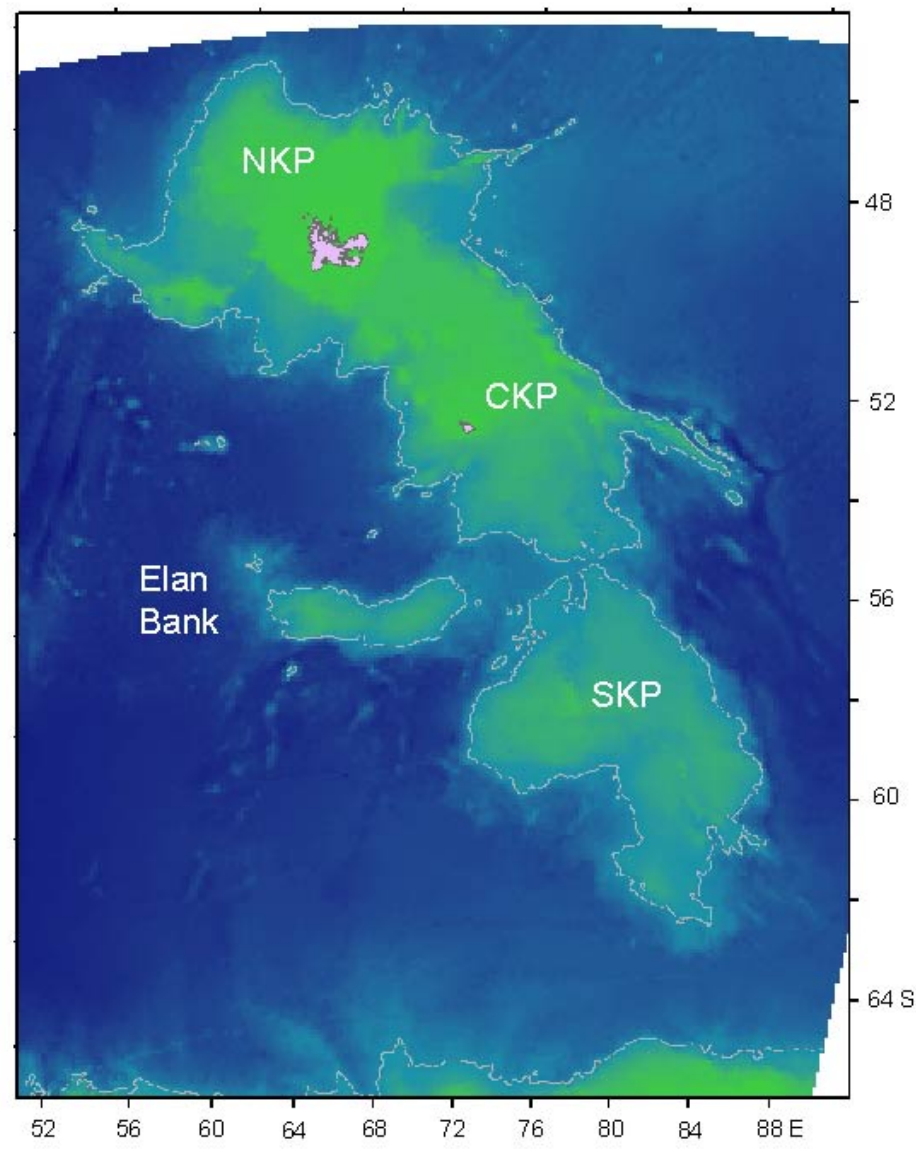

Figure 5. Bathymetric map of the Kerguelen Plateau region using a different color scheme than that of the Australian submission. NKP - Northern Kerguelen Plateau; CKP - Central Kerguelen Plateau; SKP - Southern Kerguelen Plateau. Land areas are shown as gray: Heard and McDonald Islands are immediately beneath and to the left of CKP; the Îles Kerguelen (Îles de Désolation) archipelago is just below the " $P$ " in NKP. This color scheme emphasizes water depths less than 2,500 $\mathrm{m}$ (in greens) and greater than 2,500 $\mathrm{m}$ (in blues). The $2500-\mathrm{m}$ isobath is shown as a dotted contour. In this image, the color scaling minimizes the appearance of connectivity from the CKP to either Elan Bank or SKP This map was created in a Geographic Information System using ETOPO2 bathymetry.

The Central Kerguelen Plateau (CKP) is the keystone of the Australian submission, for without Heard and MacDonald Islands on it, there would be no basis for an Australian claim. They are the only Australian islands in the South Indian Ocean. While most of the NKP is within $100 \mathrm{~m}$ of sea level, most of the CKP is deeper (excepting the small area that encompasses Heard/McDonald Islands). The geologic boundary between the NKP and the CKP is marked by differences in age as well as crustal structure and composition (Frey and others, 2000). The NKP, including the archipelago, is composed of Hawaiian-type flood basalt rocks that are less than 45 
million years old. In addition, the seismic velocity and thickness of the crust are also characteristic of a mid-plate volcanic island, such as Hawaii (Charvis and others, 1995). To the south, the CKP is composed mostly of older rocks that were emplaced during a short time in the Cretaceous (around $100 \mathrm{Ma}$ ) contemporaneously with Broken Ridge, a submarine plateau further north in the Indian Ocean (Coffin and others, 2002; Wallace and others, 2002). Heard and McDonald Islands are formed by recent volcanism, and may indicate that the modern Kerguelen plume has migrated southward from the Îles Kerguelen (Îles de Désolation) archipelago to the present location of Heard/McDonald Islands (Weis and others, 2002). The crustal rocks beneath the CKP are thicker and strongly suggest excessive volcanism related to an active spreading center site over a hotspot, similar to the geologic setting of Iceland (Charvis and others, 1995).

The NKP and CKP, therefore, are two domains resulting from two distinctly different processes (mid-plate volcanism and oceanic-ridge spreading), which occurred at different times. Both processes are completely oceanic, and no continental rocks have been found in or on the NKP and the CKP. The EEZ boundaries that surround the Îles Kerguelen (Îles de Désolation) and Heard and MacDonald Islands are relatively straightforward. UNCLOS A 76 specifically excludes from the continental shelf the deep ocean floor with its ridges. The islands of the Kerguelen Plateau are the result of deep ocean floor processes.

The CKP has natural bathymetric boundaries separating it from the two other major segments of the Kerguelen Plateau: the Southern Kerguelen Plateau (SKP) and Elan Bank. In addition, the CKP has little or no geologic ties or continuity to either the SKP or Elan Bank.

The boundary between the CKP and the SKP lies along a series of bathymetric depressions at about 2,600 - 3,000 $\mathrm{m}$ water depth near $55^{\circ} \mathrm{S}$ (Frey and others, 2000). There are no islands on the SKP part of the greater Kerguelen Plateau region, and it is more deeply submerged than the CKP. One small portion is shallower than $1000 \mathrm{~m}$; otherwise it is generally at 1,300-1,500 m. The ocean floor dips gently away from the plateau at about $3500 \mathrm{~m}$ (Fig. 5). The SKP is the oldest part of the Kerguelen Plateau, having formed between approximately $120 \mathrm{Ma}$ and $110 \mathrm{Ma}$ (Coffin and others, 2002). It is about 20 million years older than the CKP and has an entirely different crustal structure (Coffin and others, 2000; Frey and others, 2000). There are subtle traces of continental crust material within the drill cores recovered from the SKP (Neal and others, 2002). These findings clarify plume, plate, and magma processes in the region, but they do not demonstrate geologic or morphologic continuity that is essential for establishing natural prolongation.

To the south of the NKP and to the southwest of the CKP lies Elan Bank, which, like the SKP, rises only to depths of about 1,300 m, except for one small area on the western side of the bank less than 1,000 m. Drilling on the bank at ODP site 1137 yielded "clasts of garnet-biotite gneiss, a rock type that is commonly found only in continental crust," (Coffin and others, 2000). This information is important because it shows that Elan Bank was likely a piece of India during the separation of India from Antarctica that became isolated on the Australian plate by a mid-ocean ridge jump (Borissova and others, 2003; Ingle and others, 2002). While it has been affected by volcanism that occurred simultaneously with or slightly more recently than in the nearby SKP, its geologic history is unrelated to the adjacent pieces of the Kerguelen Plateau. It is bathymetrically and geologically distinct (Coffin and others, 2000; Coffin and others, 2002). Its continental-type rock is neither above sea level nor is it a natural component of any adjacent continental margin. 
As discussed earlier, the Kerguelen Plateau submission does not illustrate the bathymetry in adequate detail. The color shading does not provide a clear depiction of the morphologic boundaries, the FOS, or the 2,500-m contour. The Australians appear to extend their claim seaward $100 \mathrm{~nm}$ from the 2,500 $\mathrm{m}$ isobath around the western and southern reaches of Elan Bank. It is clearly important to determine without question whether Elan Bank is geologically and perhaps bathymetrically part of the NKP or the CKP.

A final note on the Kerguelen Plateau submission is that a $60 \mathrm{Nmi}$ line is used to connect point S1, the westernmost point defining the France-Australia bilateral boundary, to point 2, which is positioned using Article 76, 4(a) (ii), $60 \mathrm{Nmi}$ from the foot of the continental slope (of Elan Bank). An alternative and more restrictive designation of the boundary would be to continue the $60-n m$ points until they intersected with the $200-\mathrm{nm}$ boundary around Heard/McDonald Islands (dashed line on Figure 5).

Region 5: LORD HOWE RISE (For ECS location, see http://www.un.org/Depts/los/clcs_new/submissions_files/aus04/Maps/lhr_map_es2.pdf )

The submission on Lord Howe Rise expands the 200-nm boundary both to the south, north, and east around Lord Howe Island. To the south, the boundary is extended along the Lord Howe Rise until it connects with the Australia-New Zealand 2004 treaty boundary. To the north, it is extended to the Australia-France 1982 treaty boundary. To the east, these international boundaries encompass the eastern extension of the Lord Howe Rise to connect with the Norfolk Island 200-nm boundary of Three Kings Ridge (Region 9). Because of these bilateral agreements, there is little to inspect about Article-76 issues in the Lord Howe region.

Three points are worth noting. First, Lord Howe Island and the nearby Ball's Pyramid are volcanic islands, constructed of basalt by hot-spot volcanic activity. They are believed to have formed over a mantle plume similarly to the origin of the Hawaiian Islands. They differ from Hawaii, however, because they formed on the western edge of the Lord Howe Rise, which is determined to have originated from thinned continental crust that rifted away from eastern Australia about $75 \mathrm{Ma}$ by short-lived sea-floor spreading in the Tasman Sea (Gaina and others, 1998). We assume that the continental origin for the Lord Howe Rise is the basis for extending the continental shelf across the gap between the Lord Howe and Norfolk Island 200-nm limits. The continental origin for the Lord Howe rise provides the justification for generating a continental slope and rise seaward of the 200-nm limit and incorporating them into the ECS the region that lies beyond the 200-nm limit up to the bilateral boundaries with France (to the north, points R18-R20) and New Zealand (to the south, points ANZ 23-25 and ANZ 20-21).

Second, the southwest boundary of the Lord Howe Rise is formed by points 1 to $117 \mathrm{a}$, which are mostly identified as being $60 \mathrm{~nm}$ from the foot of the continental slope. The sketchy bathymetry shown in the Executive Summary appears to support these points. However, as noted in the discussion of the Kerguelen Plateau region, the bathymetric coloring does not permit clear distinctions.

Finally, the rationale behind the hour-glass shape of the 200-nm boundary associated with Lord Howe Island is unclear. The shape is presumably derived from combining the 200-nm circular boundary from Lord Howe Island and the 200-nm circular boundary of 2 reefs north of Lord Howe Island (Fig. 6). These reefs are Elizabeth Reef, about $90 \mathrm{~nm}$ to the north, and 
Middleton Reef, about $30 \mathrm{~nm}$ north of Elizabeth Reef. It is unclear in the Executive Summary whether these reefs sustain "human habitation or economic life," and therefore qualify to be islands under UNCLOS. A Geoscience Australia web site dated 08 March 2004 states that the Coral Sea Islands "are still uninhabited today ... Unmanned weather stations, beacons, and a lighthouse are located on several other islands and reefs. ... There is no fresh water." ${ }^{3}$ However, the Australian Coral Sea Islands Territory east of the Great Barrier Reef goes well beyond $200 \mathrm{~nm}$ from the most farthest-offshore barrier reefs and offshore weather station islands (Stagg and others, 2002). It appears that Willis Island (near $16^{\circ} \mathrm{S}$ and $150^{\circ} \mathrm{E}$ ), which has a permanent weather station, serves as the basis for placing the maritime boundary halfway between Australia and Papua New Guinea. To the east, the Australians show their extended boundary out to the vicinity of $15^{\circ} \mathrm{S}$ and $158^{\circ} \mathrm{E}$, based on the Coral Sea Islands Act of 1969. Presumably the Australians were able to claim all this area by taking advantage of UNCLOS Articles 122-123 on Enclosed and Semi-enclosed Seas. These articles allow the bordering states to divide among themselves a gulf, basin, or sea that is surrounded entirely or primarily by the territorial seas or 200-nm boundaries of the coastal States. The Coral Sea is not nearly as enclosed or semi-enclosed as the Bering Sea or the Gulf of Mexico, which are regarded by the U.S. and its neighbors as enclosed or semi-enclosed seas. The question is whether CLCS will let stand the boundaries set by Australia and other coastal States using Articles 122 and 123 to divide up the international sea floor in this region.

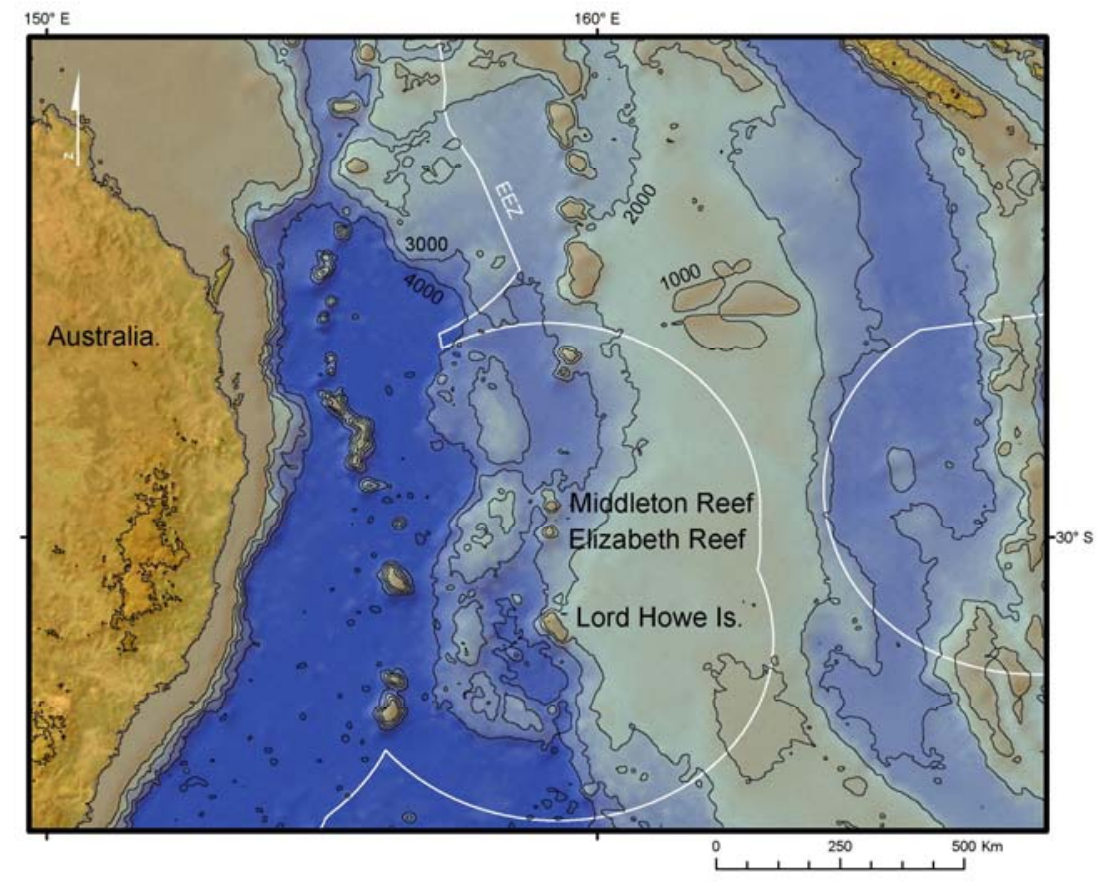

Figure 6. Map showing the location of Elizabeth and Middleton Reefs relative to Lord Howe Island. Contour Interval is $1,000 \mathrm{~m}$.

Some parts of the western margin of Lord Howe Rise are underlain by continental rift basins. These may contain as much as $3 \mathrm{~km}$ of sediment that are potential hydrocarbon source rocks

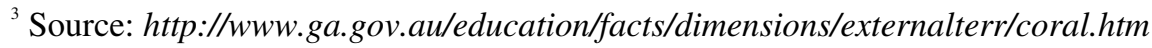


because of elevated thermal histories. East of Lord Howe Island, a more conventional continental shelf and slope petroleum province could exist in association with a basin containing more than 2 $\mathrm{km}$ of terrigenous sediments. However, the prospects are listed as "unknown" north of Lord Howe Island, "fair to poor" for the western rift basins of Lord Howe Rise, and "fair" for the eastern Lord Howe Rise (Hill and others, 2001).

Region 6: MACQUARIE RIDGE (For ECS location, see http://www.un.org/Depts/los/clcs_new/submissions_files/aus04/Maps/mac_map_es2.pdf )

The continental shelf boundary for Macquarie Island consists approximately one third of bilateral boundary points with New Zealand (the north and east), approximately one third of points that use the 60-nm formula estimation (southeast, south, and southwest), and approximately one third that are the 200-nm boundary of Macquarie Island (west and northwest).

The Article 76 issue with Macquarie Island is the legitimacy of using the 60 -nm formula to extend the "continental margin" of the island beyond $200 \mathrm{~nm}$, and possibly beyond $350 \mathrm{~nm}$ (southernmost points of the boundary). Macquarie Island is composed primarily of oceanic volcanic rocks and their eroded equivalents in local sedimentary deposits. It sits on a linear topographic ridge that follows with the Australia-Pacific plate boundary south of New Zealand (Meckel and others, 2003). Transpression along this plate boundary has resulted in uplift of the 1,500-km long Macquarie Ridge complex, of which Macquarie Island is the only subaerial exposure (Daczko and others, 2003). The crust on both sides of the Australia-Pacific plate boundary is oceanic. Macquarie Island is unique on Earth for being the only " subaerial exposure of non-plume-related-oceanic crust that still lies within the basin in which it formed," (Daczko and others, 2003). Macquarie Island is therefore indisputably oceanic in its origin and present state, and lies wholly along an oceanic ridge, albeit not a mid-ocean spreading ridge.

Region 7: NATURALISTE PLATEAU (For ECS location, see http://www.un.org/Depts/los/clcs_new/submissions_files/aus04/Maps/nat_map_es2.pdf )

Naturaliste Plateau is probably the least questionable area of the Australian submission. This plateau is a submerged extension of the southwest Australian landmass. Of the 424 points defining the extended shelf boundary, 100 are set by the constraint lines ( 90 by the depth constraint line; 10 by the $350 \mathrm{~nm}$ constraint line). The rest are based on the bathymetric formula line. Clearly this region is entitled to the full benefit of Article 76.

The composition of the plateau is mixed, with the western part consisting of sediments. (Symonds and Wilcox, 1989). These authors rate the petroleum prospects as poor.

Region 8: SOUTH TASMAN RISE (For ECS location, see http://www.un.org/Depts/los/clcs_new/submissions_files/aus04/Maps/str_map_es2.pdf )

The South Tasman Rise is a submerged portion of the southern Australian landmass making this a relatively uncontroversial area of the Australian submission. All but four of the 647 points defining this boundary are based on the $60-\mathrm{nm}$ formula; the four points on the eastern boundary are based on the sediment thickness formula. This region appears to be entitled to the full benefit of Article 76. 
This region has two contiguous components, the South Tasman Rise and the East Tasman Plateau. A deep water saddle at about 3,000 m exists between the continental shelf and slope of Tasmania and both the southerly Rise and eastern Plateau regions. This saddle is clearly inside the 200-nm line, thus any issues of structural continuity are probably moot. Two ocean-drilling legs have greatly contributed to understanding the South Tasman Rise and East Tasman Plateau: DSDP Leg 29 in 1973 and ODP Leg 189 in 2000.

This region of Australia underwent multiple rifting events, plume-volcanism episodes, and adjustments in sea-floor spreading directions during the continental break-up around eastern and southern Australia (Hill and Exon, 2004). The South Tasman Rise is a continental fragment stranded on the Australian plate during the separation of Australia and Antarctica between approximately 80 and $33 \mathrm{Ma}$ (Lawver and Gahagan, 2003). It initially developed as a complex, extended, faulted regime separating north-south sea floor spreading between Australia and Antarctica and east-west spreading between Australia and the Lord Howe Rise (and eastern) regions. The westernmost section of the South Tasman Rise probably broke off the Coates Land margin of Antarctica (Lawver and Gahagan, 2003).

The East Tasman Plateau is considered to be a continental fragment from either the Lord Howe Rise (Gaina and others, 2003) or from Tasmania (Hill and Exon, 2004) which has been overprinted by younger volcanism (Cascade Seamount) that affected this entire region of the southeastern Australian continental margin.

Region 9: THREE KINGS RIDGE (For ECS location, see http://www.un.org/Depts/los/clcs_new/submissions_files/aus04/Maps/tkr_map_es2.pdf )

Most of the Three Kings Ridge region is bounded by bilateral boundaries with neighboring nations. Only two points on the northeast utilize the $60-\mathrm{nm}$ bathymetric formula. If we grant legitimacy to those boundaries, including the short segment of boundary labeled "200 M from territorial sea baseline of an opposite or adjacent State," there is not much to question here. These international boundaries are used without additional information to extend the ECS boundary (e.g., points ANZ 2 - ANZ 8).

Like the Lord Howe Rise region, the Three Kings Ridge region has a complicated tectonic history because of the multiple episodes of rifting, volcanism, and sea-floor spreading that occurred during the continental break-up that left Australia as an independent continent (Bernardel and others, 2002). The picture is further complicated by plate boundary interactions to the east with the Pacific Ocean along the compressional boundary now at the Tonga-Kermadec trench (Bernardel and others, 2002). This complex geology is manifested by the complicated morphology of the region. Both the Norfolk Ridge and the Three Kings Ridge are considered to have thinned continental crustal roots, although the continental rocks inferred in Three Kings Ridge are mixed with the more voluminous island arc complexes. As with other regions noted in the Australian submission, the criteria used to pick the foot of the slope in this area of complex bathymetry are unclear.

Region 10: WALLABY AND EXMOUTH PLATEAUS (For ECS location, see http://www.un.org/Depts/los/clcs_new/submissions_files/aus04/Maps/wep_map_es2.pdf ) 
The Wallaby and Exmouth Plateaus lie adjacent to western Australia (Fig. 1). The 966 points used to define the extended continental shelf are a mix of the 60-nm bathymetric formula (132 points), the depth constraint line (543 points) and the $350-\mathrm{nm}$ constraint line (230 points). This region of the Australian submission appears to be similar to the Naturaliste Plateau to the south; i.e., it is an extension of the western Australian landmass.

The Wallaby Plateau represents either a submarine volcanic plateau (Colwell and others, 1994) or a microcontinent associated with intense volcanism and ridge jumps during the continental separation between northwestern Australia and India (Brown and others, 2003; Gaina and others, 2003). The hydrocarbon potential of the Wallaby Plateau is considered negligible because of the volcanic activity and large water depths (Sayers and others, 2002).

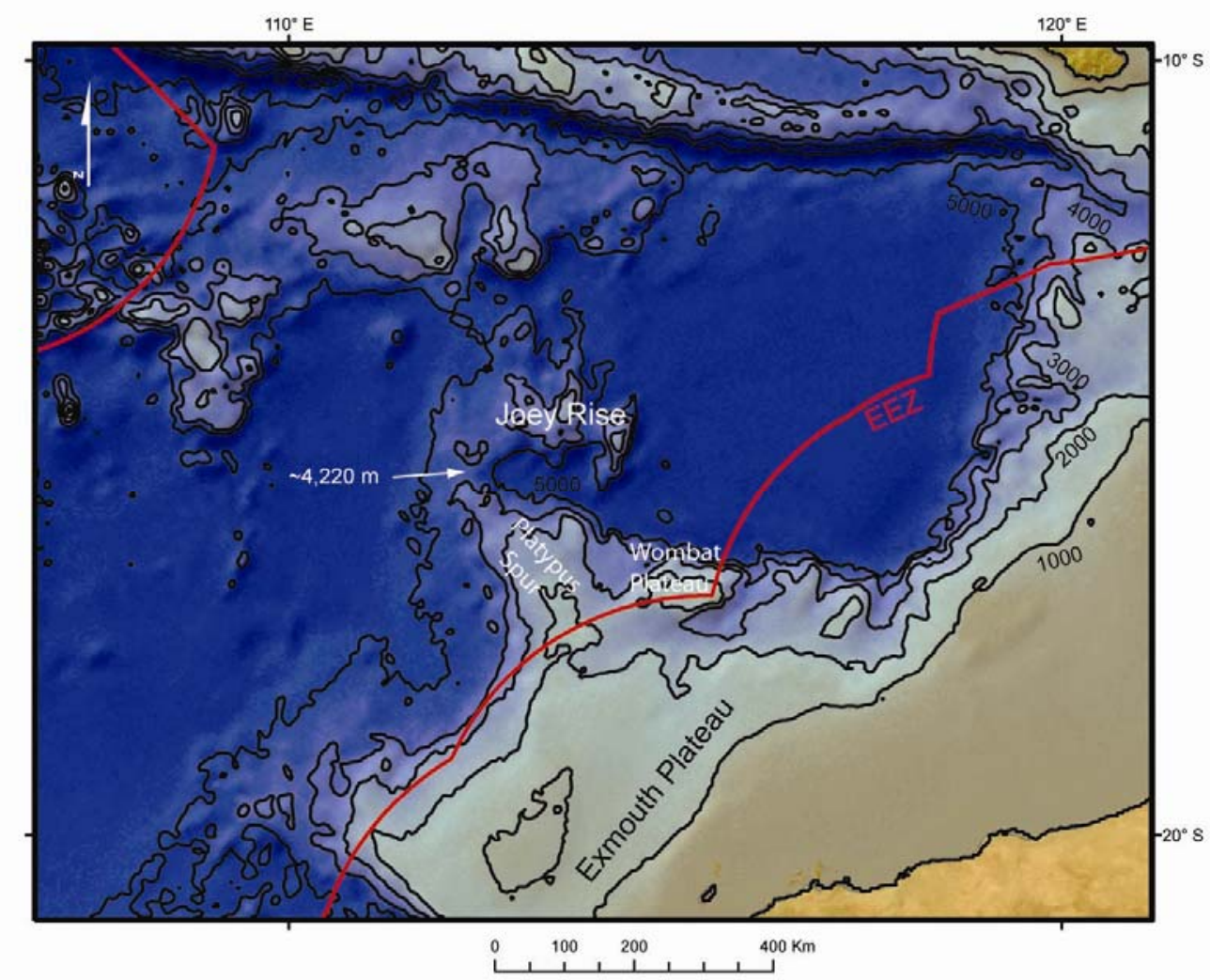

Figure 7. Bathymetry around the Wallaby and Exmouth Plateaus showing the extension of Joey Rise north of the Exmouth Plateau. The linear morphologic boundary formed by Wombat Plateau and Platypus Spur is created by a fault separating oceanic crust to the north from continental transitional crust of the Exmouth Plateau. Contour Interval 1,000 m.

Like the Wallaby Plateau, the Exmouth Plateau is probably underlain by stretched continental crust (Brown and others, 2003) and can be considered an extension of the Australian landmass. One concern is the interpretation of the $60-\mathrm{nm}$ formula line in the northern Exmouth Plateau and how the bathymetric extensions of the plateau are treated. These features are, from the continent on the east to the ocean on the north, the Wombat Plateau, the Platypus Spur, and the Joey Rise (Fig. 7). The linear morphologic boundary on the northern side of the Wombat Plateau 
and the Platypus Spur forms an escarpment that marks the continent-ocean boundary that was once a transform fault during sea-floor spreading (Brown and others, 2003). The Joey Rise, however, lies on oceanic crust, based on identification of marine magnetic anomalies and results from ODP Leg 123, hole 765, which drilled into oceanic basaltic crust slightly to the east of the Rise in the Argo Abyssal Plain (Sayers and others, 2002). It is therefore presumably formed by oceanic volcanism. However, it appears that points 2-149 of the extended continental shelf boundary use the base of the Joey Rise as the foot of the continental slope. The bathymetric saddle that connects Platypus Spur to Joey Rise is at about 4,200 m, or at deep ocean depths and lies completely outside the Australian 200-nm boundary. The issue is whether the Joey Rise, located above a different crustal type and only connected to the larger Exmouth Plateau at deep ocean depths that are well outside the 200-nm limit, can be considered an extension of the continental landmass. When the CLCS reviews this boundary, a precedent is likely to be set on allowable extensions of the landmass.

It is also interesting to note that the extended continental shelf in the region is significantly larger in the final submission than on earlier extended continental shelf drawings (Symonds and Wilcox, 1989). Apparently new geologic data or a more aggressive interpretation of Article 76 has caused the Australians to extend their submission lines in this area.

\section{Conclusions}

The continental shelf submission of Australia presents the CLCS with a large and complicated delimitation of ECS boundaries. How the CLCS resolves these issues may set precedents for future submissions under UNCLOS. The Australian submission also offers many analogies for understanding how the U.S. might define extended continental shelf around its continental margin.

\section{Acknowledgments}

Maps in this report were prepared using ArcGIS 9.0 and ETOPO2 bathymetry. We thank Richie Williams and Jeff Williams for critical reviews of the draft of this report. We thank Jon Childs, Ginger Barth, Mark Simonoff, and Bob Smith for enlightening discussions.

\section{References Cited}

AMBIS, 2001, Australian Maritime Boundary Information System (AMBIS): Geoscience Australia, http://www.ga.gov.au/nmd/products/thematic/ambis.jsp.

Bernardel, G., Carson, L., Meffre, S., Symonds, P., and Mauffret, A., 2002, Geological and morphological framework of the Norfolk Ridge to Three Kings Ridge region: Australian Geological Survey Organization Record 2002/08, 76 pp.

Borissova, I., Coffin, M.F., Charvis, P., and Operto, S., 2003, Structure and development of a microcontinent; Elan Bank in the southern Indian Ocean: Geochemistry, Geophysics, Geosystems - G (super 3), v. 4, no. 9, 16 pp. 
Brown, B., Mueller, R.D., Gaina, C., Struckmeyer, H.I.M., Stagg, H.M.J., and Symonds, P.A., 2003, Formation and evolution of Australian passive margins; implications for locating the boundary between continental and oceanic crust, in Hills, R.R., and Mueller, R.D., eds., Geological Society of America, Special Paper, v 372, p. 223-243.

Charvis, P., Recq, M., Operto, S., and Brefort, D., 1995, Deep structure of the northern Kerguelen Plateau and hotspot-related activity: Geophysical Journal International, v. 122, no. 3, p. 899-924.

Coffin, M.F., and Eldholm, O., 1994, Large igneous provinces; crustal structure, dimensions, and external consequences: Reviews of Geophysics, v. 32, no. 1, p. 1-36.

Coffin, M.F., Frey, F.A., Wallace, P.J., and others, 2000, Leg 183 summary; Kerguelen PlateauBroken Ridge; a large igneous province: Proceedings of the Ocean Drilling Program, Part A; Initial Reports, v. 183, p. 101.

Coffin, M.F., Pringle, M.S., Duncan, R.A., Gladczenko, T.P., Storey, M., Mueller, R.D., and Gahagan, L.A., 2002, Kerguelen hotspot magma output since 130 Ma: Journal of Petrology, v. 43, no. 7, p. 1121-1139.

Colwell, J.B., Symonds, P.A., and Crawford, A.J., 1994, The nature of the Wallaby (Cuvier) Plateau and other igneous provinces of the West Australian margin: AGSO Journal of Australian Geology and Geophysics, v. 15, no. 1, p. 137-156.

Daczko, N.R., Wertz, K.L., Mosher, S., Coffin, M.F., and Meckel, T., 2003, Extension along the Australian-Pacific transpressional transform plate boundary near Macquarie Island, in Reddy, S.M., Fitzsimons, I.C.W., and Collins, A.S., eds., Abstracts - Geological Society of Australia, v. 72, p. 23.

Frey, F.A., Coffin, M.F., Wallace, P.J., Weis, D., Zhao, X., Wise, S.W., Jr., Waehnert, V., Teagle, D.A.H., Saccocia, P.J., Reusch, D.N., Pringle, M.S., Nicolaysen, K.E., Neal, C.R., Mueller, R.D., Moore, C.L., Mahoney, J.J., Keszthelyi, L., Inokuchi, H., Duncan, R.A., Delius, H., Damuth, J.E., Damasceno, D., Coxall, H.K., Borre, M.K., Boehm, F., Barling, J., Arndt, N.T., and Antretter, M., 2000, Origin and evolution of a submarine large igneous province; the Kerguelen Plateau and Broken Ridge, southern Indian Ocean: Earth and Planetary Science Letters, v. 176, no. 1, p. 73-89.

Gaina, C., Mueller, D.R., Royer, J.-Y., Stock, J., Hardebeck, J.L., and Symonds, P., 1998, The tectonic history of the Tasman Sea; a puzzle with 13 pieces: Journal of Geophysical Research, B, Solid Earth and Planets, v. 103, no. 6, p. 12,413-412,433.

Gaina, C., Mueller, R.D., Brown, B.J., and Ishihara, T., 2003, Microcontinent formation around Australia, in Hills, R.R., and Mueller, R.D., eds., Geological Society of America, Special Paper, v. 372, p. 405-416.

Hill, P., Rollet, N., and Symonds, P., 2001, Seafloor mapping of the South-east Marine Region and adjacent waters - AUSTREA final report; Lord Howe Island, south-east Australian margin (includes Tasmania and South Tasman Rise) and central Great Australian Bight: Australian Geological Survey Organization Record 2001/08, 83 pp. 
Hill, P.J., and Exon, N.F., 2004, Tectonics and basin development of the offshore Tasmanian area incorporating results from deep ocean drilling: Geophysical Monograph, v. 151, p. 19-42.

Ingle, S., Weis, D., and Frey, F.A., 2002, Indian continental crust recovered from Elan Bank, Kerguelen Plateau (ODP Leg 183, Site 1137): Journal of Petrology, v. 43, no. 7, p. 12411257.

Krassay, A.A., and Totterdell, J.M., 2003, Seismic stratigraphy of a large, Cretaceous shelf-margin delta complex, offshore southern Australia: AAPG Bulletin, v. 87, no. 6, p. 935-963.

Lawver, L.A., and Gahagan, L.M., 2003, Evolution of Cenozoic seaways in the Circum-Antarctic region, in Florindo, F., Cooper, A.K., and O'Brien, P.E., eds., Palaeogeography, Palaeoclimatology, Palaeoecology, p. 11-37.

Longley, I.M., Bradshaw, M.T., and Hebberger, J., 1999, Australian petroleum provinces of the 21st century: American Association of Petroleum Geologists Bulletin, v. 83, p. 2037.

Meckel, T.A., Coffin, M.F., Mosher, S., Symonds, P., Bernardel, G., and Mann, P., 2003, Underthrusting at the Hjort Trench, Australian-Pacific plate boundary; incipient subduction?: Geochemistry, Geophysics, Geosystems - G (super 3), v. 4, no.12, 30 pp.

Neal, C.R., Mahoney, J.J., and Chazey, W.J., III, 2002, Mantle sources and the highly variable role of continental lithosphere in basalt petrogenesis of the Kerguelen Plateau and Broken Ridge LIP; results from ODP Leg 183: Journal of Petrology, v. 43, no. 7, p. 1177-1205.

Nur, A., Ben-Avraham, Z., 1982, Oceanic plateaus, the fragmentation of continents, and mountain building: Journal of Geophysical Research, B, v. 87, no. 5, p. 3644-3661.

Sayers, J., Borissova, I., Ramsay, D., and Symonds, P.A., 2002, Geological framework of the Wallaby Plateau and adjacent areas: Australian Geological Survey Organization Record 2002/21, 85 pp.

Stagg, H.M., Alcock, M.B., Borissova, I., and Moore, A.M., 2002, Geological framework of the southern Lord Howe Rise and adjacent areas: Australian Geological Survey Organization Record 2002/25, 104 pp.

Symonds, P.A., and Wilcox, J.B., 1989, Australia's petroleum potential in areas beyond an Exclusive Economic Zone: Bureau of Mineral Resources, Geology and Geophysics, v. 11, p. 11-36.

Wallace, P.J., Frey, F.A., Weis, D., and Coffin, M.F., 2002, Origin and evolution of the Kerguelen Plateau, Broken Ridge and Kerguelen Archipelago; editorial: Journal of Petrology, v. 43, no. 7 , p. 1105-1108.

Weis, D., Frey, F.A., Schlich, R., Schaming, M., Montigny, R., Damasceno, D., Mattielli, N., Nicolaysen, K.E., and Scoates, J.S., 2002, Trace of the Kerguelen mantle plume; evidence from seamounts between the Kerguelen Archipelago and Heard Island, Indian Ocean: Geochemistry, Geophysics, Geosystems - G (super 3), v. 3, no.6, 16 pp. 